\title{
The Antinomy of Workers' Control in Socialist Eastern Europe
}

\author{
Adrian Grama
}

How might the experiences of East European workers between 1945 and 1989 fit into a general history of the left in the twentieth century? ${ }^{1}$ Writing in the mid-199os, the great Italian trade union leader Bruno Trentin offered one possible answer. La Città del lavoro, his bitter indictment of the Western European labour movement's failure to respond to the crisis of Fordism, makes the story of state socialism central to understanding the setback of trade unionism after the 1970s. ${ }^{2}$ The book narrates an all too familiar history of defeat: the increased mobility of capital after the termination of Bretton Woods, coupled with the emergence of transnational value chains and the relocation of production away from the core industrialized countries spelled the end of Fordism as a model of growth rooted in a specific "post-war" social order. ${ }^{3}$ Against this background, according to Trentin, trade unions found themselves confronted with a double challenge. First, in Italy and other West European countries, the sheer range of employment relations expanded to accommodate new forms of less secure, more precarious work contracts. Second, inside factories, management successfully secured control of the production process, reorganizing work teams, pushing for speed-ups and redesigning work schedules.

Less familiar is Trentin's explanation for the historical failure of the labour movement to negotiate a favourable transition out of Fordism. ${ }^{4}$ This failure

1 For comments and criticism, I thank Goran Musić, Ștefan Guga, Andrei State, Pieter Troch, the members of the social anthropology study group at the Graduate School for East and Southeast European Studies in Regensburg/Munich and last but not least the editors of this volume.

2 Bruno Trentin, La città del lavoro: Sinistra e crisi del fordismo (Milan: Feltrinelli, 1997).

3 From a vast body of literature, see Andrew Glyn, Capitalism Unleashed: Finance, Globalization, and Welfare (Oxford: Oxford University Press, 2007), 104-129; Jeffry A. Frieden, Global Capitalism: Its Fall and Rise in the Twentieth Century (New York: W.W. Norton \& Company, 2007), 363-385; Robert Brenner, The Economics of Global Turbulence: The Advanced Capitalist Economies from Long Boom to Long Downturn, 1945-2005 (London: Verso, 2006), 145-229.

4 It falls outside the scope of this article to evaluate Trentin's overarching argument about the historical trajectory of the left in the twentieth century. It is worth noting that La Città del lavoro is a polemical book, deeply rooted in the Italian debates of the 1970 and Trentin's

(C) ADRIAN GRAMA, 2021 | DOI:10.1163/9789004440395_008

This is an open access chapter distributed under the terms of the CC-BY-NC 4.o license.rian Grama - 9789004440395 Downloaded from Brill.com04/26/2023 12:16:40PM 
was not merely contingent on national contexts and economic sectors, but structural, grounded in the original sin of its early twentieth-century founding fathers, Lenin and Gramsci. Trentin argued that this was because irrespective of their differences, the two shared a fascination for Taylorism and Fordism as the embodiment of science and progress. Their combined legacy, in the East and the West, was an across-the-board acceptance of both Taylorism and Fordism as neutral production technologies that could generate economic growth, when placed under collective property regimes. ${ }^{5}$ Their followers throughout the century - whether communist parties in power in the Soviet Union after 1921 and Eastern Europe after 1947, or socialist parties partaking in the postwar economic boom of Western Europe - carried on from this initial fascination, adapting variants of scientific management and borrowing the toolkit of Fordism to fashion planned and market economies alike. Western European trade unions, according to Trentin, turned their attention away from the factory floor and enthusiastically supported various productivity bargains well into the 1970s, making wages and working time the cornerstone of their struggles. These redistributive strategies left union leaders unprepared to grasp the crisis

own experiences within the Italian (communist) labour movement. A critique of Trentin's book would arguably focus on his narrow conception of Fordism, his sidelining of socialdemocracy and of the various experiments with the humanization of labour relations during the postwar epoch. Moreover, such a critique would also call for a more encompassing notion of "the left" that can accommodate its manifold traditions.

5 Trentin understood Fordism much along the lines sketched by Antonio Gramsci in the early 1920s. From this point of view, Fordism was on the one hand a technology of production defined by the large-scale, vertically integrated industrial plant, standardized production and the assembly line. On the other hand, Fordism was also a technology of mass consumption, to the extent that it pioneered higher wages and directly helped the expansion of nationally-embedded markets for durable goods. For Trentin, however, Fordism also rested on a trade-off between higher wages and higher productivity in which the former were seen as a precondition for the latter. The notion of "workers' control" denoted this precise trade-off - workers' shop-floor solidarity had to be constantly dislodged (or at least fought against) in order for the assembly line to run according to managerial imperatives rather than workers' established work routines and rhythms. See, first, Antonio Gramsci, "Americanism and Fordism", in Selections from the Prison Notebooks, trans. ed. Quinn Hoare and Geoffrey Smith (New York: International Publishers, 1971), 277-318. For Trentin's uses of the concept, see Mimmo Carrieri, "Tra politica e organizzazione del lavoro: Fordismo da regolare, Taylorismo da controllare", in Bruno Trentin: Lavoro, libertà, conoscenza, ed. Alessio Gramolati and Giovanni Mari (Florence: Firenze University Press, 2010), 95-106. For a partial review of various definitions of Fordism, see Adelheid von Saldern and Rüdiger Hachtmann, "Das fordistische Jahrhundert. Eine Einleitung", Zeithistorische Forschungen 2, no. 6, (2009): 174-185. For Fordism as a "regime of accumulation" that cannot explain the dynamics of a centrally planned economy, see Marcel Drach, "Crise du travail et non-lieu du fordisme dans les économies de type soviétique", Revue d'études comparatives East-Ouest 14, no. 1 (1983): 105-120. 
of Fordism and the ensuing managerial revolution that transformed the dynamics of industrial production.

Moreover, Trentin suggested, voices critical of the acceptance of Taylorism and Fordism on the left were seldom given their due. Therefore, La Città del lavoro revisits forgotten figures such as Simone Weil and Georges Friedmann, both of whom allegedly better understood the darker side of celebrating the productive capacity of scientific management. However, Trentin was also critical of his fellow trade unionists in Italy and beyond for having ignored the writings of East European dissidents such as Rudolf Bahro and Miklós Haraszti that could have taught them about the "oppressive character" of such production technologies under state socialism. ${ }^{6}$ Lastly, Trentin's book might be read - as Alain Supiot argues - as a plea to rethink the relationship between citizenship and work; a relationship that ought to entail remaking the factory floor into a terrain of the struggle for rights. ${ }^{7}$ How, then, would such a goal be served by the writings of these East European critics of scientific management? Or to put it differently, how adequate is the representation of state socialism seen through the writings of Bahro and Haraszti? Is Trentin's story of a gradual loss of workers' control over the production process - however contentious for Western Europe after 1945 - valid for Eastern European state socialism?

The current chapter is arranged in four steps. In the first section, I show that the representation of the state socialist production process that one obtains from dissidents such as Haraszti and Bahro does not satisfactorily explain the dynamics of the shop floor in Eastern Europe after 1947. Because workers under state socialism enjoyed a comparatively higher degree of autonomy at the point of production, stories of deskilling tend to distort the facts. Instead, I argue that we need to revisit the importance of skills and turn the spotlight onto the craft masters of the assembly lines. Conceptually, this move involves paying more attention to currently obsolete categories of analysis in global labour history, such as "workers' control". In the second section, I show how the productivity bargain never really came to define the relationship between management and workers under state socialism. The idea of a productivity bargain was that higher levels of productivity, and implicitly less control over the production process on the part of the workers, would be traded off against higher wages. However, this was difficult to implement under state socialism and in a context in which repressed consumption was the norm of capital accumulation. The third section moves on to a comparative assessment of what I call

6 Bruno Trentin, La città del lavoro. Sinistra e crisi del fordismo (Milan: Feltrinelli, 1997), 35, 117.

7 Alain Supiot, "Introduction", in La Cité du travail. Le fordisme et la gauche, ed. Bruno Trentin (Paris: Fayard, 2012), 28. 
the "antinomy of workers' control" in Eastern Europe. This antinomy refers to the fact that in all socialist countries of the East, reforming wage relations was the exclusive way of dislodging workers' entrenched control of production. For central planners, workers' autonomy on the shop floor was conducive to what they called "wage levelling" and "norm over-fulfilment", accompanied by a supposed loss of motivation and low productivity. For industrial managers, workers' autonomy was a safety net for coping with the inherent shortages occurring in a shortage economy. These two middle sections of the chapter draw on empirical material from the monitoring section of Radio Free Europe (RFE). Lastly, in the concluding remarks I reflect on Trentin's interpretation of the fate of the left in the twentieth century in light of the trajectory of labour in Eastern Europe after 1989.

\section{The Slightly Eerie Abstraction}

It is not hard to understand what Bruno Trentin found appealing in the writings of Rudolf Bahro. On the one hand, Bahro had a good knowledge of the East German shop floor and, much like Trentin himself, was interested in the creative potential of work. ${ }^{8}$ In interviews with the West German media, Bahro repeatedly pointed out that East German workers suffered from a lack of work morale and that they were caught up in a system of "organized irresponsibility". ${ }^{9}$ The alienating effects of Taylorism were part of the story. Yet even more important was the structure of politics in communist societies, with the party ruling hierarchically from the top down and thus curtailing any attempts to democratically organize the production process. On the other hand, Bahro's most famous book, Die Alternative, put forward the argument that communist parties in power across Eastern Europe were pursuing a politics of growth that was antithetical to the emancipation of labour. Under state socialism, production for the sake of production did trickle down to the workers in the form of mass consumption, but the price of "quantitative compensation" was political subordination; or what Bahro famously called Subalternität. ${ }^{10}$

8 Rudolf Bahro, Plädoyer für schöpferische Initiative: Zur Kritik von Arbeitsbedingungen im real existierenden Sozialismus (Köln: Bund Verlag, 1980).

9 See, for example, the interview with Lutz Lehmann in Rudolf Bahro, Eine Dokumentation (Köln: Europäische Verlangsanstalt, 1977), 98 and passim.

10 Rudolf Bahro, Die Alternative. Zur Kritik des real existierenden Sozialismus (Köln: Europäische Verlangsanstalt, 1977), 190. 
In these arguments, Trentin might have found confirmation of his own intuitions. Bahro's concern with the emancipating, creative potential of work resonated with Trentin's guiding idea of providing workers with the tools for pursuing "liberazione e autorealizzazione nel lavoro"." Equally important, the emphasis on the logic of "quantitative compensation" in Die Alternative sounded remarkably similar to Trentin's own attack on the strategy of productivity bargaining, through which Western trade unions gave up control of the shop floor in favour of higher wages and a larger share of the growth pie. ${ }^{12}$ In other words, the East German dissident could have been taken as criticizing a variety of Fordism; an impoverished one for certain - and one backed by a repressive political order - but nevertheless one that could be acknowledged as such. Fordism, after all, had been an object of admiration, transplantation and local adaptation in the early Soviet Union. As Stefan Link put it, in the interwar period, modernizers of all sorts "were attracted by the immense gains in productivity brought about through the rationalized production organization and full utilization of automatic machinery found in Fordism."13 Soviet leaders dreamt of an "Americanized Bolshevism", and Soviet industrial experts regarded Fordism as "the decisive repudiation of craft-based principles". ${ }^{4}$

It was therefore reasonable to assume that a variety of Fordism structured the planned economies of state socialism, and it was equally reasonable to argue that Taylorism ruled the socialist assembly line. Miklós Haraszti's $A$ Worker in a Worker's State depicted a shop floor structured by an alienating form of remuneration - piece-work - the unfolding of which subjugated workers to machines, crushing them under the pressure to meet ever higher output targets. ${ }^{15}$ Haraszti found the piece-rate system and its associated practice of norm-setting to be the epitome of exploitation and the best symbol of the perversion of socialism. During his trial in October 1973, he declared before the

11 Alessandro Casellato, "Bruno Trentin", Belfagor 64, no. 3 (2009): 308 (emphasis in the original).

12 Trentin describes here what Charles Maier called "the politics of productivity", namely the bundle of industrial policies that underpinned the boom of the West European economies during the 1950s and 196os. Charles S. Maier, "The Postwar Social Contract", International Labor and Working-Class History 50 (1996): 148-156.

13 Stefan Link, "Transnational Fordism: Ford Motor Company, Nazi Germany, and the Soviet Union in the Interwar Years" (PhD Dissertation, Harvard University, 2012), 9.

14 David E. Greenstein, "Assembling Fordizm: The Production of Automobiles, Americans, and Bolsheviks in Detroit and Early Soviet Russia", Comparative Studies in Society and History 56, no. 2 (2014): 259-289; Link, "Transnational Fordism", 7.

15 Miklós Haraszti, $A$ Worker in a Worker's State. Translated by Michael Wright (New York: Universe Books, 1978). 
judge that piece-rate working was a capitalist, not a socialist institution. Yet the logic of the system was not merely exploitative, because no matter what forms of solidarity workers might develop on the shop floor, it was the sense of generalized powerlessness that pervaded the socialist factory. Workers had little control over the production process, and even less over the dynamics of norms and income.

This was a bleak picture indeed. In form rather than intent, Haraszti's book resembled the genre of the factory reports produced by incognito activists in the aftermath of May 1968, of which Robert Linhart's L'Établi is arguably the most famous. It went to great lengths to describe the rhythms and routines of the shop floor, paying attention to clues that might indicate the possibility for oppositional sentiment among workers. ${ }^{16}$ One reviewer noted with some disappointment the sheer ambiguity of this strategy:

Evil is equated with the status quo while Good is left as an undefined alternative. One may agree or disagree with him, but in neither case can one really acquire any deeper insight or understanding of the author's reality - the only explanation allowed is the Evil attributed to the deus ex machina, be it called 'Them', a 'New Ruling Class', 'Communist Totalitarianism', or whatever. At the same time, the deus ex machina quality that makes A Workers' State - along with much other dissident writing ultimately unsatisfying as literature is the main source of its notoriety as a political document: the same Manichaeism making it politically inadmissible in the East gave it all too warm a welcome in the West. ${ }^{17}$

Literary style and political implications aside, Trentin might have cared more about Haraszti's thick description of work under state socialism, notably the impact of Taylorism run amok.

Yet in this respect too, academic sociologists found Haraszti's grasp of the shop floor problematic. Michael Burawoy, who took up work in several Hungarian factories during the early 1980 os to test out his comparative sociology of "factory regimes", found Haraszti's book "a work of critique, not explanation".18 Because the book presented a "picture of atomized, oppressed, alienated,

16 Robert Linhart, L'Établi (Paris: Editions de Minuit, 1981). For more on the établissement literature in France, Italy or the United States, see the special issue dedicated to the topic in Les Temps Modernes, Ouvriers volontaires les années 68, 3-4, no. 684-685 (2015).

17 Ellen Turkish Comisso, “A Worker in a Worker's State”, Telos 21, no. 54 (1982): 218.

18 Michael Burawoy and János Lukács, The Radiant Past. Ideology and Reality in Hungary's Road to Capitalism (Chicago: Chicago University Press, 1992), 3 o. 
degraded working class" in order to pit it against an ideal socialist society, the end result could not be anything other than a description of a "homogenized society with no dynamics or variation", not unlike the simplified paradigm that framed the research agenda for Soviet area studies in American universities for much of the Cold War. ${ }^{19}$ A more serious objection, however, is related to Haraszti's choice to universalize his experience, implying that all work under state socialism resembled the bundle of characteristics he observed at the Red Star factory on Csepel Island. This "slightly eerie abstraction", the editors of New Left Review suggested, was parallel to abstract labour itself, indicating that no matter how different one task is from another, labour under state socialism became homogeneous and thus replaceable: "Haraszti's silence as to its location emphasizes the similarity of conditions elsewhere". ${ }^{20}$ Burawoy saw differently:

The most distinctive difference was our conception of social relations on the shopfloor. Haraszti painted a picture of atomized individuals, and here I think he was projecting his own (unreflected) placement within the factory. As a dissident, a Jew and an intellectual, he was shunned by his fellow workers. He was thrown into competition with them, he was ruled by them, and he was most certainly not one of them. To be sure, I was not one of them either - but my strangeness had an appeal. They laughed at my inept Hungarian and at my incompetence as a machine operator, and I was embraced as an exotic foreigner. Within hours of hitting the shopfloor, I was ringed by workers asking me about the USA. From my vantage point, I could see and experience the spontaneous cooperation that made production possible in the socialist factory. ${ }^{21}$

"Spontaneous cooperation", linked to what Burawoy would later identify as workers' autonomy on the shop floor, was one side of what I term here as "workers' control". The other side of it was, pace Haraszti's editor at the New Left Review, workers' irreplaceability; a phenomenon most clearly identified by another Hungarian sociologist carrying out research on Csepel Island in the 1970s. István Kemény was equally interested in the effects of Taylorism on Hungarian workers, but rather than focusing on the piece rate remuneration system, he started out from the observation that in centrally-planned economies,

19 Ibid.

20 "Introduction to Miklós Haraszti", New Left Review, no. 91 (May-June, 1975): 6.

21 Michael Burawoy, "Working in the Tracks of State Socialism", Capital \& Class 33, no. 2 (2009): 45-46. 
the more rigid the plan is, the more flexible the production process becomes. In this context, it was the practical knowledge, autonomy and initiative of the skilled workers that kept production going amidst shortages galore. Without doubt, Kemény's workers were equally as exploited as were Haraszti's; their labour on the assembly line was monotonous and repetitive, while their official wages could barely keep them above the poverty line. In reaction to these grim circumstances, two intertwined processes took shape: first, skilled workers engaged in extra hours, working well beyond the eight-hour legal norm in order to boost their take-home pay; second, the very same skilled workers exercised a high degree of control over the rhythms of the production process:

Most every gesture is indeed mechanical, but the general deployment of work is not. From a certain point of view, workers are able to control what they are doing on the shop floor, yet their work is less easily controllable. They have come to master every detail that pertains to the pace of work. It is during extra hours that they can better control and adjust the pace of work. Those among workers employed by the pre-assembly workshop can even control it during the regular working day. But even the skilled assembly workers can dictate their own pace of work, which means that neither the rhythms of the assembly line nor the norm set for its various tasks are particularly tight. The choice of technology, of work methods and tools is determined by objective conditions. However, within the limits of these objective conditions, each worker on the assembly line freely chooses his methods and devices. He selects his own tools, sometimes he even manufactures them, or he simply invents new ones. [...] No worker on the assembly line has the possibility to influence the quality and quantity of the produced goods. The production of these goods is subjected to the tyranny of the monthly plan, as well as to the quantity and quality of tools and component parts available at any given time. Workers are less able to exert control over the duration of their work. If they can manage to achieve in only four hours what they were supposed to do in eight, it is obvious they cannot afford themselves to work only four hours a day. ${ }^{22}$

Writing in the 1970s - a decade of crisis and transformation for capitalism, but also one of intense labour militancy across the developed economies

22 István Kemény, "La chaîne dans une usine hongroise", Actes de la recherche en sciences sociales, Vol. 24 (1978): 75-76 (my translation). 
of Western Europe and North America - David Montgomery felt compelled to go back to the turn of the century in order to explore the competing visions of organizing the shop floor that emerged out of workers' resistance to scientific management. Much like Bruno Trentin, Montgomery understood that the transition out of Fordism plays out as much on the shop floor as away from it, and he attempted to revisit the past experiences of workers' opposition to earlier managerial revolutions of the production process. The central figures in this story were the so-called "quintessential workers": male, white, skilled master craftsmen, predominantly in metal industries, who engaged in the defence of their autonomy at the point of production via union and non-union methods. ${ }^{23}$ These were, in short, the type of workers targeted by scientific management, as their control of the shop floor was taken to reside "in the superiority of their knowledge over that of the factory owner". ${ }^{24}$ Montgomery emphasized that he was not writing about the traditional clash between artisanal routines and industrial discipline, but rather about:

[T] he patterns of behavior which took shape in the second and third generations of industrial experience, largely among workers whose world had been fashioned from their youngest days by smoky mills, congested streets, recreation as a week-end affair and toil at the times and the pace dictated by the clock (except when a more or less lengthy layoff meant no work at all). It was such workers, the veterans, if you will, of industrial life, with whom Taylor was preoccupied. ${ }^{25}$

The concept of workers' control, after a moment of fame during the heyday of social history, did not fare well. ${ }^{26}$ Comparative historical sociologists found Montgomery's depiction of the everyday struggle for control at the point of production a welcome insight into the emergence of labour militancy at the

23 With regard to the notion of "quintessential worker", see Sonya O. Rose, "Class Formation and the Quintessential Worker", in Reworking Class, ed. John R. Hall (Ithaca: Cornell University Press, 1997), 133-166.

24 David Montgomery, Workers' Control in America: Studies in the History of Work, Technology, and Labor Struggles (Cambridge: Cambridge University Press, 1979), 9.

25 Ibid, 10.

26 See the studies collected in Jonathan C. Brown, ed., Workers' Control in Latin America, 1930-1979 (Chapel Hill: The University of North Carolina Press, 1997). More recently, Immanuel Ness and Dario Azzellini, ed., Ours to Master and To Own. Workers' Councils from the Commune to the Present (Chicago: Haymarket Books, 2011), 172-19o. 
turn of the century; not only in the United States but also across continental Europe. ${ }^{27}$ It certainly helped that the notion itself was already part of the political language forged by workers' representatives during the general strikes and failed revolutions of the late 1910 s and early 192 os. $^{28}$ Empirical sociologists exploring the abodes of production, however, opted to speak of labour rather than of workers' control; perhaps a more neutral term, unencumbered by historical legacies and hence more readily adapted to scholarly research. ${ }^{29}$ The meaning of the two terms is practically interchangeable, both denoting what David Harvey called the "perpetual guerrilla warfare" on the shop floor between management and workers around the issue of just how much autonomy the latter might enjoy in decisions concerning the piece rates, the distribution of tasks, personnel and workloads, the rhythms of work or the adoption of new technology. ${ }^{30}$

Be that as it may, the historiographical revolution that swept across the field of labour history over the recent decades has brought about new research objects and moved beyond the concern with such "veterans" of industrial life. The concept was devoid of any explanatory value for writing histories of marginal and marginalized workers, women, racial minorities and immigrants, just as it was when the centre stage of historical research was taken by the integrated working consumer of mature Fordism. The global turn in labour history also entailed leaving behind the factory as the main arena for investigating the fate of the working multitude: farmlands and sweatshops, the informal economy of the Global South and the expanding service sector of the Global North were all inhabited by different workers, for whom exerting control at the point of production was barely a question at all. Nor was the question particularly salient for workers defending their livelihood against capital relocation, plant closures

27 Carmen Sirianni, "Workers' Control in Europe: A Comparative Sociological Analysis", in The Experience of Labor in Europe and America 1900-1925, ed. James E. Cronin and Carmen Sirianni (Philadelphia: Temple University Press, 1983), 254-310.

28 Georges G. Assan, La question du contrôl ouvrier en Italie, avec un aperçu dans les autres pays (Paris: Marcel Giard, 1922).

29 The body of literature is vast and multifaceted. For a discussion of labour control around the issue of workplace alcohol consumption, see Michel Pialoux, "Alcool et politique dans l'atelier. Une usine de carrosserie dans la décennie 1980s", Genèses 7, no. 1 (1992): 94-128. For a gendered analysis of labour control linking labour market dynamics and factory regimes, see Ching Kwan Lee, Gender and the South China Miracle: Two Worlds of Factory Women (Berkeley: University of California Press, 1998). Taking into account company size, the classic typology of labour control remains Richard Edwards, Contested Terrain: The Transformation of the Workplace in the Twentieth Century (New York: Basic Books, 1979). David Harvey, The Limits to Capital (London: Verso, 2006), 117. 
and looming unemployment. ${ }^{31}$ Nevertheless, with regard to understating the historical trajectory of state socialism in Eastern Europe after 1945, the concept remains seminal for two complementary reasons.

One reason is structural, and derives from the logic of the centrally-planned economy. Against the background of full employment, these economies invariably generated a higher demand for labour relative to supply, creating recurrent labour shortages, particularly with regard to skilled workers. ${ }^{32}$ In turn, these labour shortages endowed specific groups of workers across industry with significant bargaining power, which translated into control of the production process. ${ }^{33}$ In conjunction with labour shortages, the socialist shortage economy imparted high mobility on the less skilled, usually younger workers, for whom job switching within the same industrial sector or even across sectors became common. This turnover of personnel - a genuine obsession for communist industrial relations experts - only reinforced the control of the production process the skilled minority enjoyed. The main consequence of this runaway dynamic, as I show below, was the equally recurrent attempts of communist policymakers to reform the wage system and periodically experiment with wage dispersion ratios and incentive schemes.

The other reason is contingent, and emerged out of what the late Mark Pittaway called "the Stalinist revolution in production"; a process of translation and adaptation of Soviet labour relations to Eastern Europe during the early 1950s. ${ }^{34}$ The revolution unfolded together with the exponential growth of the working class across the region, beginning in the late 1940s. One of its premises (and promises) were to dislodge the pre-war working-class culture, forge a new socialist work culture and integrate new generations of industrial youth, women and workers of peasant origin. Stakhanovism, for example, was regarded as a training method for the unskilled, who could circumvent traditional apprenticeship routines through a sheer commitment to a higher pace of work. It is

31 The above paragraph summarizes the arguments of Nelson Lichtenstein, "David Montgomery and the Idea of 'Workers' Control' ", Labor. Studies in Working-Class History of the Americas 10, no.1 (2013): 68-69.

32 The classic analysis is János Kornai, The Socialist System: The Political Economy of Communism (Oxford: Claredon Press, 1992).

33 In other words, it is the structural logic of the shortage economy that makes the form of workers' control I describe here unique. For while empirically similar processes could also be observed across market economies, explanations for the occurrence and/or persistence of workers' control under those conditions would most likely identify the rigidity of the labour market or the power of trade unions as causal mechanisms.

34 Mark Pittaway, "The Reproduction of Hierarchy: Skill, Working-Class Culture, and the State in Early Socialist Hungary", The Journal of Modern History 74, no. 4 (2002): 737-769. 
no wonder that the most hated workers of the time were precisely the same Stakhanovists - so-called "labour heroes" - who challenged the established rhythms of the production process by working faster. The famous burning brick scene in Andrzej Wajda's Man of Marble (1976) must have been an everyday reality for quite a few "labour heroes" ${ }^{35}$ In practice, therefore, the revolution only produced a deeply segmented working class, with skill, gender, social origin and age acting as markers for exclusion and marginalization. In Hungary and other socialist countries of the region, the early 195os led to a reproduction of hierarchy at the shop floor level, allowing for the skilled minority of veteran, urban workers to retain their control of the production process and reach informal bargains with management over access to better tools, raw materials and higher wages. In this formative context, workers' control was not merely a form of resistance against the Stalinist revolution in production; it was also a ground for cooperation between skilled workers and management. ${ }^{36}$

This brief incursion into the reception of Miklós Haraszti's $A$ Worker in a Worker's State by representatives of the West European left shows a fundamental misunderstanding about the nature of the state socialist shop floor. For readers such as Bruno Trentin, Haraszti's book was supposed to confirm the original sin of the global labour movement, originating from the embrace of Fordism and Taylorism by Lenin and Gramsci. This early commitment to supposedly neutral production technologies produced either entire socialist societies built on the "tyranny of the norm", homogenization and the exploitation of the working class, or - as with the Italian trade unions of the 197os and 1980 - labour leaders blinded by the promise of higher wages and hence incapable of mounting any opposition to post-Fordism at the point of production. However, a closer look at the socialist shop floor reveals a different picture, as no matter how exploitative labour relations were in Eastern Europe after 1945, the system was premised on a minority of skilled workers being able to

35 The scene, halfway through the film, follows the main character - the Stakhanovist worker Mateusz Birkut - on tour. As a "labour hero", Birkut travelled through Poland from one construction site to another to hold demonstrations on the art of laying bricks, working faster and better than the average labourer. On one such construction site, immersed in the process of erecting a wall, Birkut is handed a hot brick, which instantly burns his hands and stops the demonstration. This is a typical depiction of acts of resistance by workers against the higher pace of work forced on them by the Stakhanovist movement.

36 The cooperation aspect has often been ignored in literature by authors who assign little explanatory value to the shortage economy and instead emphasize the exploitative nature of the relationship between management and workers. For example, see Donald Filtzer, "Labor Discipline, the Use of Work Time, and the Decline of the Soviet System, 1928-1991", International Labor and Working-Class History 5० (1996): 9-28. 
dominate the production process and exert control over the pace of work, the distribution of tools and the division of tasks. Rather than a gradual loss of workers' control under the combined impact of Fordism, Taylorism and higher wages, the state socialist regimes of the East exhibited an inverse historical dynamic: higher wages resulting from the ability of a segment of workers to master the production process.

What, then, of Bahro's "quantitative compensation" - the supposed socialist equivalent of the productivity bargains that structured the post-war boom in Western Europe? Was this a more accurate description of the socialist labour relations that might suggest the presence of Fordism east of the river Elbe? Fordism, after all, does not exclude workers' control altogether. As Simon Clark argued, the Fordist organization of work proceeds by a strict separation of skills, grounded in a dual labour market "composed of a small stratum of skilled workers and a mass of unskilled immigrant workers". ${ }^{37}$ The separation of skills is also conducive to increased interdependence, which makes the vertically integrated modern large-scale factory ever more vulnerable to various breakdowns along the supply chains and production lines. This in turn requires a certain degree of flexibility on the part of the workforce. The need for flexibility might then open up room for manoeuvre for some workers, allowing them to reconquer their autonomy at the point of production. It is for this reason that the perennial problem of Fordism is workers' control (what sociologists call "labour control"), which tends to manifest itself in various ways; from quota restrictions and the deterioration of quality, to goldbricking and other forms of foot dragging. The resolution of this problem of workers' control in Fordism usually takes the form of the "five-dollar day" (that is, higher wages).

Romanian industrial experts and their peers across Eastern Europe were, of course, not unaware of this method of resolution. An entire strand of literature published throughout the 1950s, sometimes translated from Soviet sources, purported to analyse the wide gamut of problems that plagued supply chains and production lines. The vocabulary developed to grasp the haphazard supply of raw materials or breaks in the production process aimed to underline the crucial duty of managers and workers alike to maintain the steady flow of

37 Simon Clarke, "What in the F---'s Name is Fordism", in Fordism and Flexibility: Divisions and Change, ed. N. Gilbert, R. Burrows and A. Pollert (London: Macmillan, 1992), 19. 
production. So-called "bottlenecks" are an example of one such pathology of industrial production. This referred to the practice of intermittent work due to the chaotic supply of necessary raw materials, thus causing clogging. "Storming" was the other side of the coin. Once raw materials finally arrived at the workbench, workers were summoned to make up for the lost time and put their effort into achieving the planned output targets. More serious, however, was the issue of "overblown" or "over-fulfilled" norms, which - as Kemény argued - was often associated with working extra hours. For industrial experts, the over-fulfilment of norms indicated various forms of workers' control at the point of production, through which some workers could appropriate better tools and materials, enter into agreements with the supervisory personnel and increase their income. In so doing, however, they were believed to distort productivity indicators. Let us take one example from the first decade of state socialism in Romania.

In May 1950, an aspiring young journalist by the name of Radu Cosaşu took up a job in one of Bucharest's leading metal factories, then named Timpuri Noi (New Times). Of middle-class background, Cosaşu became a committed communist at the end of the war and set out to explore the daily life of the working class out of a mix of ideological persuasion and party sanctions for his bourgeois upbringing and family connections. This experience would make it, thirty years later, into his justly celebrated novel, Armata mea de cavalerie, a first-person fictionalized retelling of the author's biographical trajectory. The fragment that builds on Cosaşu's first-hand knowledge of factory work revolves around a made-up conflict between a skilled worker by the name of Dinu and the author's alter-ego, an apprentice lathe operator, the details of which do not concern us here. What is important for the argument in this chapter is the work routine that Cosaşu unwittingly recorded in his novel. Dinu would regularly divide his working month into two periods: one in which he could afford to take it easy, fool around and devote time to training his apprentice; and a second one, just before the payday, when Dinu would work without any interruptions, neglect everything else and break the norm..$^{38}$ This latter timeframe was dubbed by Cosaşu perioada vânătă (roughly translated as the darkened period); days during which Dinu was so focused on over-fulfilling the norm and securing a higher income for himself that no horseplay, and not even ordinary chat, was tolerated around the lathe. Any attempt by the apprentice to trouble Dinu during his darkened period would often result in physical punishment,

38 Radu Cosaşu, Opere IV. Supravieţuirile: 1. Rămăşşţele mic-burgheze, 2. Armata mea de cavalerie (Iaşi: Polirom, 2011), 184-210. 
the exact opposite of the jovial and friendly atmosphere Dinu created around himself for the rest of the month, when his spirits were so high that he cavalierly tolerated myriad mistakes on the part of the apprentice.

Perhaps no other depiction of workers' control is more apt than Cosaşu's metaphor. It stood for Dinu's ability to thoroughly control the routine of the shop floor, dictating the pace of work and the level of take-home pay; not only for himself, but also for his apprentice. Nothing was more damaging to the entire socialist norm-setting and wage system than the ups and downs of the darkened periods. Industrial experts in Romania and beyond regarded such displays of workers' control as inimical to higher productivity, and nothing but bulwarks against attempts to rationalize industrial work and push for efficiency. The most common answer to this perceived pathology of the shop floor was the so-called policy of "mutual material interests" (cointeresare materială) - the state socialist equivalent to the productivity bargain of Fordism. ${ }^{39}$ The scope of this "mutual material interests" arrangement was to empower management in undertaking the transition from so-called "statistical-experimental" to "technical-economical" norms. The first type of norms governed much of industrial production in socialist Romania up to the late 1950s: they were arrived at through informal negotiations between management, norm-setters and some of the most experienced workers in various branches of industry, and were supposed to record the maximum output per worker expected, given the existing machinery. The second type of norms relied far less on the practical input of the skilled workers and would be decided, in turn, by planning and ministerial agencies on the basis of the technological specifications of the machinery and other "objective" production indexes. Extending "technical-economical" norms across industry was believed to increase productivity per worker and make Dinu's darkened periods the rule rather than the exception in the working month. In other words, this was the socialist strategy of enforcing managerial control over the shop floor with the aim of boosting efficiency. ${ }^{40}$

What could workers expect in exchange for accepting the work rhythm of the "technical-economical" norms? In a similar way to the Fordist productivity bargain, they could enjoy higher take-home pay. The socialist wage was divided into two main component parts: first, the basic or "tariff" wage, which was compounded according to the type of industry, difficulty

39 I. Blaga and F. Burtan, Principiul leninist al cointeresării materiale (Bucharest: Editura Politică, 1961).

40 For a similar dynamic in the interwar Soviet Union, see Lewis Siegelbaum, "Soviet Norm Determination in Theory and Practice, 1917-1941", Soviet Studies 36, no. 1 (1984): 45-68. 
of tasks, nature of working conditions and skill; second, on top of the tariff wage there was an entire, often highly complex, system of premiums and bonuses that rewarded dedication, dexterity and commitment to higher output. In principle, both components of the socialist wage were dependent on fulfilling output targets: the norms for the tariff wage were usually within the reach of every worker irrespective of age, skill level, gender or location in the production process; the norms for receiving premiums and bonuses were harder to fulfil, at least by those who lacked experience, access to better tools and a steady supply of materials. Dinu, for example, would typify a worker in the first category. For much of the working month he would be content with working to the extent necessary to secure the tariff wage, all according to his own pace of work and established routine. In his "darkened period", however, Dinu would push himself hard to amass as many premiums and bonuses as possible, thereby increasing his wage. For the vast mass of unskilled workers, young apprentices and fresh recruits to factory work, such darkened periods did not exist. Their take-home pay would amount to the tariff wage alone, and they were seldom able to engage in episodes of norm-breaking.

The logic of this wage system was deeply divisive and skewed towards a minority of skilled, usually male, veteran workers, who were able to earn significantly more due to their privileged position in the production process. However, it was precisely this minority of "quintessential workers" who could profit most from the system and appropriate its logic for higher income - that effectively hindered the proper functioning of norms. Their control of the production process afforded them the luxury of taking it easy on some days and making up for this on others; a dialectic of working time and task fragmentation that was the very opposite of Taylorism. The haphazard supply of materials characteristic of a shortage economy only reinforced their privileged position, as management could rely on their commitment on those occasions when "storming" was deemed necessary. In this context, the socialist variety of productivity bargaining premised on "mutual material interests" could only alter the significance of the tariff wage in the sum total of the take-home pay. The first major wage reform in socialist Romania implemented at the end of the 1950s raised the proportion of the tariff wage from just above 50 per cent to over 70 per cent across industrial branches. At the same time, tighter norms elaborated by industrial experts replaced the allegedly obsolete "statistical-experimental norms" that had guided industrial output for the first post-war decade. The immediate consequence of this reform was a general wage increase for unskilled workers and a slight decrease in the income of the skilled ones, the latter having been 
suddenly confronted with harder to achieve target outputs via premiums and bonuses. ${ }^{41}$

By the mid-196os, Romanian policymakers were contemplating yet another overhaul of the wage system. In little under a decade, the scenario seemed to be repeating itself. A report commissioned by the government in 1967 noted with some alarm that in many cases, workers were receiving inadequate norms, since as much as one quarter of the entire workforce was able to "overfulfil" norms by 130 per cent. ${ }^{42}$ Therefore, the new wage reform insisted on redressing the balance in favour of efficiency, and once again boosting the tariff wage at the expense of premiums and bonuses. As the RFE expert monitoring Romania put it:

The better part of income from exceeding norms and premiums achieved so far as additional benefits, will in the future be included in the tariff wage. In this way, the worker or employee will be more interested than in the past in the tariff wage and thus will be more anxious than formerly to qualify for a higher tariff wage. It appears that in the past, by consensus of management, the trade unions, etc., the norms were artificially kept low so as to facilitate the fulfilment of certain plan indices. The workers relied increasingly on the over-fulfilment of norms. Norms were often not raised internally although new and more productive machinery was introduced. The new wage system, which practically envisages a considerable increase of norms, will provide a higher income from the tariff wage but a lower one from exceeding norms. On balance, the workers will profit only if he manages to be highly efficient and his industrial unit prosperous (the criterion will be the sale of marketable production or export). ${ }^{43}$

In their basics, the Romanian wage reforms of the late 1950s and late 196os were essentially identical. Both offered much the same solution to virtually the same problem: the tariff component of the workers' take-home pay was pushed up with the hope of empowering management to impose tighter, supposedly more scientific norms and mine for efficiency deep in the abodes of

41 For an extensive analysis of this reform see Adrian Grama, Laboring Along. Industrial Workers and the Making of Postwar Romania (Berlin: De Gruyter, 2019), 232-242.

42 ANR, PCM, 6/1967, 11.

43 "Situation Report: Romania, 13 October 1967", 13 October 1967. HU OSA 30o-8-47181-15; Records of Radio Free Europe/Radio Liberty Research Institute: Publications Department: Situation Reports; Open Society Archives at Central European University, Budapest. 
production. It could not have been otherwise. When the tariff component of the wage made only half of the take-home pay, as was the case up to 1957, the hindrance to increased productivity was high wage dispersion. A wide gap between the income of the skilled and the unskilled, resulting from the first being able to over-fulfil their norms, perpetuated a situation in which the majority of workers eking out a living on the tariff wage alone could hardly have had any interest in over-performing on the shop floor, let alone the means to do so. High wage dispersion, therefore, was incompatible with the strategy of "mutual material interests". Giving the tariff wage more weight in the final wage, however, was equally troublesome. First, as the report mentioned above observed, at least a quarter of workers were still able to earn significantly more through their control over the production process. Second, in the longer term, increasing tariff wages tended to drastically reduce wage dispersion, a phenomenon that communist policymakers dubbed "levelling" (see table below). It is little wonder that in 1973, a new wage reform was deemed necessary in socialist Romania; this time not to redress the norm of over-fulfilling, but instead to widen again the gap between the wages of the skilled workers and the rest of the workforce. ${ }^{44}$

The logic of wage reform under state socialism made plain the sheer difficulty of implementing productivity bargains in a shortage economy. Yet what also frustrated the strategy of "mutual material interests" was the overall intention of policymakers to keep the cost of labour low. ${ }^{45}$ Because socialist economies were geared towards overinvestment in capital goods at the expense of mass produced consumer goods, the most common growth pattern available to policymakers was repressed consumption, which allowed the planning apparatus to divest funds away from consumption (and implicitly, light industry). ${ }^{46}$ Harry Trend, the RFE expert on wage policy, correctly noted in a survey of the various wage reforms undertaken across Eastern Europe during the mid-196os that

44 The wage differential was supposed to be cut from 1.92 to 1.45. See "Situation Report: Romania, 7 December 1973", 7 December 1973. HU OSA 300-8-47-193-21; Records of Radio Free Europe/Radio Liberty Research Institute: Publications Department: Situation Reports; Open Society Archives at Central European University, Budapest, 9.

45 For a general assessment, see also "Wage Differentials and Economic Reform in Eastern Europe”, 2 May 1966. HU OSA 30o-8-3-159o8; Records of Radio Free Europe/Radio Liberty Research Institute: Publications Department: Background Reports; Open Society Archives at Central European University, Budapest.

46 Even during the 1970s, a decade that saw a relative boost of private consumption in Romania, the catchword remained consumers' "sacrifice". See Ronald H. Linden, "Socialist Patrimonialism and the Global Economy: The Case of Romania", International Organization 40, no. 2 (1986): 364. 
TABLE 6.1 The dynamic of wage dispersion before and after the 1967 wage reform

\begin{tabular}{llrrr}
\hline $\begin{array}{l}\text { Wage } \\
\text { group in lei } \\
(6 \text { lei = 1 \$) }\end{array}$ & $\begin{array}{l}\text { 1960 } \\
\text { (in \% of total } \\
\text { workforce) }\end{array}$ & 1965 & 1967 & 1970 \\
\hline up to 700 & 37.5 & 15.2 & - & \\
$701-1,000$ & 35.8 & 36.0 & 38.5 & - \\
$1,001-1,5$ O० & 21.6 & 35.0 & 40.9 & 23.5 \\
$1,501-2,5$ O० & 4.7 & 12.6 & 18.3 & 47.3 \\
over 2,500 & 0.4 & 1.2 & 2.3 & 4.2 \\
\hline
\end{tabular}

SOURCE: "SITUATION REPORT: ROMANIA, 18 OCTOBER 1967", 18 OCTOBER 1967. HU OSA 300-8-47-181-17; RECORDS OF RADIO FREE EUROPE/RADIO LIBERTY RESEARCH INSTITUTE: PUBLICATIONS DEPARTMENT: SITUATION REPORTS; OPEN SOCIETY ARCHIVES AT CENTRAL EUROPEAN UNIVERSITY, BUDAPEST, 3

even if nominal wages were to go up, this would be "accomplished through a redistribution of existing wage payments rather than through a larger share of the savings from reductions in production costs and the introduction of improved technology or management techniques". ${ }^{47}$ The situation was not unlike the one that underpinned the South Asian export-led industrialization boom of the same decade. In both contexts, the assumption was that growth must be premised on the comparative advantage of cheap labour that emerging economies enjoyed within the global economy. ${ }^{48}$ Trend's suggestion to Eastern European communist policymakers could have very well been directed at South Korea in the 196os:

Finally, a wage policy which will largely depend on redistributive measures rather than on a change in the manner of distributing newly gained savings and on a change in economic policies favouring a more rapid

47 "The New Residual Claimant Wage System in Eastern Europe", 28 April 1966. HU osA 3008-3-159o9; Records of Radio Free Europe/Radio Liberty Research Institute: Publications Department: Background Reports; Open Society Archives at Central European University, Budapest, 3 .

48 Soon-Kyoung Cho, "How Cheap is 'Cheap Labor'? The Dilemmas of Export-led Industrialization" (PhD Dissertation, University of California, Berkeley, 1987). With regard to how Romanian economists saw the comparative advantage of low-cost labour, see Ion Rachmuth, "Trade between Countries with Different Socio-Economic Systems", Soviet and Eastern Foreign Trade 4, no. 1 (1968): 15. 
growth of the consumer sector, is bound to provide only the most meagre effects on labor productivity and the standard of living. A page from Henry Ford's policy during the twenties - "high wage - high consumption" could serve as a much better guide. ${ }^{49}$

Rudolf Bahro's notion of "quantitative compensation" and the Romanian strategy of "mutual material interests" could indeed be misread as socialist varieties of the Fordist productivity bargain. A closer look at the structural setting in which such bargains were supposed to operate reveals a different picture. First, the logic of wage reform shifted between high and low wage dispersion, which perpetuated workers' control on the shop floor, in turn making it hard for management to impose ever tighter norms in search of higher productivity. Second, even if such attempts might have occasionally been successful, the pattern of growth grounded in repressed consumption and low labour costs was at the opposite end of the spectrum from Ford's "high wage - high consumption" model. Put differently, no matter how much the fascination with such production technologies on the part of communist leaders in power, Fordist productivity bargains never quite caught on outside the capitalist core of the EuroAtlantic area. ${ }^{50}$ To interpret the industrial development under state socialism in Eastern Europe as a form of Fordism is likely to deprive the concept of all explanatory value.

Above and beyond the conceptual stakes of correcting the interpretation of state socialism Bruno Trentin derived from the writings of Bahro and Haraszti, the problems that these dissident intellectuals identified on the state

49 "The New Residual Claimant Wage System in Eastern Europe", 28 April 1966. HU osA 3008-3-15909; Records of Radio Free Europe/Radio Liberty Research Institute: Publications Department: Background Reports; Open Society Archives at Central European University, Budapest, 3 .

50 For a similar argument in Latin American labour history, see Joel Wolfe, "The Social Subject versus the Political: Latin American Labor Studies at a Crossroads", Latin American Research Review 37, no. 2 (2002): 247. Wolfe criticized his peers for mistaking factory redesign, rationalization campaigns and speed-ups for Fordism: "The key component of Fordism is a high industrial wage, for the system is predicated on increasing domestic markets for internally produced goods. Fordism is therefore defined largely by the consumption of goods and services by workers earning high wages that they often receive in exchange for labouring in monotonous and sometimes dangerous factory settings". 
socialist shop floor were real enough: lack of motivation, the atomization of the working class, low productivity and high labour turnover. Communist policymakers grappled with these alleged problems of industrial life through periodic wage reforms. Wage policies were widely regarded as the pillar of economic reforms, and often went hand in hand with the introduction of market mechanisms and the decentralization of decision-making at the level of the enterprise. Therefore, wage reforms can be interpreted as experimental attempts to overcome the inbuilt disequilibrium of the socialist command economy. ${ }^{51}$

Take, for instance, the Czechoslovak wage reform of the mid-198os, the explicit goal of which was to make the tariff wage account for over 70 per cent of the take-home pay. An earlier reform undertaken in the first half of the 1970s aimed to normalize wage scales after the crisis of 1968 and the supposed disorganization of industrial production brought about by the events leading up to the Prague Spring and its aftermath. It granted more authority to foremen, extended the three-shifts work schedule, cut down on overtime and encouraged high wage dispersion. In addition to these measures, this earlier reform also targeted workers' control, by pushing up the tariff component of the wage, tightening norms and trimming the premiums and bonuses that came with over-fulfilling norms. ${ }^{52}$ In just over a decade, Czechoslovak policymakers saw themselves forced to reform the wage system once again, because as one RFE report noted, by the mid-1980s "the variable portion of an individual's wage (the portion determined by one's performance measured against production norms) grew until it came to account for up to fifty percent of the overall wage". ${ }^{53}$ This was a clear symptom of workers' control on the shop floor that allowed some workers to engage once more in norm busting and to increase their income. Similar to the Romanian case discussed above, the Czechoslovak

$5^{1} \quad$ For a general assessment of the reforms of the 1960s across Eastern Europe, see Besnik Pula, Globalization under and after Socialism. The Evolution of Transnational Capital in Central and Eastern Europe (Stanford: Stanford University Press, 2018), 32-64.

52 "Situation Report: Czechoslovakia, 13 February 1974", 13 February 1974. HU OSA 300-847-65-7; Records of Radio Free Europe/Radio Liberty Research Institute: Publications Department: Situation Reports; Open Society Archives at Central European University, Budapest. This RFE report does not break down the reform on industrial sectors or branches, which would have arguably made it easier to grasp the many inherent contradictions of these policies.

53 "Situation Report: Czechoslovakia, 2 May 1986", 2 May 1986. HU OSA 300-8-47-817; Records of Radio Free Europe/Radio Liberty Research Institute: Publications Department: Situation Reports; Open Society Archives at Central European University, Budapest, 10. 
wage reforms attempted to eradicate norm breaking, only to see it re-emerge again in the course of a decade.

Not all wage reforms under state socialism in Eastern Europe tried to break the vicious circle of norm over-fulfilling by increasing tariff wages. The Bulgarian wage reform of 1977, for example, eliminated bonuses for norm overfulfilment and introduced a more "flexible" base salary, which would go up or down depending on the performance coefficients each worker displayed at the end of the month. ${ }^{54}$ Yet another take on the issue is represented by the early 1970s wage reform in Poland, where policymakers decided to pay more attention to the correlation between the wages of managerial staff and white-collar employees, and the remuneration of workers. While in the Czechoslovak, Romanian and Bulgarian cases the assumption was that technological upgrading coupled with workers' control rendered norms obsolete and required a reorganization of the wage system, Polish industrial experts put their money on the necessary role of supervision and expertise at the factory level. ${ }^{55}$ As RFE argued in a detailed analysis of this policy:

The worker is treated as an object, not a subject. Up to now, all incentives were, in principle, distributed down to the workers, and the size of the white-collar employee bonuses was clearly based on the achievements of the workers. The reversal of this approach - although it does prove the ability to break with deep-rooted dogmas - means that the primary target is the intensification of the activities of the management. ${ }^{56}$

Poland was, of course, an exception. In no other socialist country were workers able, and the government willing up to 1981 , to push up wages through militancy, sovereign debt and collective bargaining. Equally exceptional was the

54 "Situation Report: Bulgaria, 25 March 1977", 25 March 1977. HU OSA 300-8-47-339; Records of Radio Free Europe/Radio Liberty Research Institute: Publications Department: Situation Reports; Open Society Archives at Central European University, Budapest, 9 .

55 In his famous study of the global spread of Taylorism during the first half of the twentieth century, French sociologist Georges Friedmann noted that in those national contexts in which labour productivity was more an outcome of higher employment figures than of technological upgrading, factories would be in need of highly trained "cadres de direction et surveillance". See Georges Friedmann, Le travail en miettes. Spécialisation et loisirs (Paris: Gallimard, 1956), 17 and passim.

56 "The Draft of a New Wage System in Poland", 1 April 1970. HU OSA 300-8-3-4677; Records of Radio Free Europe/Radio Liberty Research Institute: Publications Department: Background Reports; Open Society Archives at Central European University, Budapest, 5 . 
Yugoslav case; a socialist state that allowed unemployment, strikes and labour migration to Western Europe. Here, wage reforms took on a similar dynamic to that recognizable in market economies. On the one hand, the economic reforms of the mid-196os, granted labour-managed firms control over wages and investments, with deep consequences for the labour market. As Leonard Kukić put it: "even though real wages had collapsed during the 1980s, existing workers were able to capture a larger share of the wage bill than could have been possible if entry of labour into existing labour-managed firms was not restricted. This behaviour resembles insider-outsider models of labour markets characterized by strong trade unions." ${ }^{57}$ On the other hand, the crisis of the 198 os in Yugoslavia was translated by policymakers into the more traditional anti-inflationary policy package of wage freezes, price controls and cuts in domestic consumption. ${ }^{58}$ This macroeconomic context, underpinned by $\mathrm{Yu}-$ goslavia's idiosyncratic industrial relations model and federalism, made problems resulting from workers' control more likely to be dealt with through the interplay of local labour markets and political compromise, rather than simply through wage reform as in the other East European socialist countries. ${ }^{59}$

By far the most interesting case of wage reform under state socialism was in Hungary. For much of the 1970s, Hungarian policymakers struggled to introduce a certain degree of wage differentiation, aiming to widen the low wage dispersion by way of rewriting classification tables and encouraging skills acquisition. One decade of wage experiments, however, only produced further egalitarian effects, so much so that by the early 1980s, a new wage reform was needed in order to restore higher remuneration for the segment of skilled workers: "It is not the purpose of the new system to promote social justice through egalitarian incomes. On the contrary, its aim is to create economic inequality based on performance because, in the regime's view, at present that seems to be the best way of improving the lot of everyone". ${ }^{60}$ This constant search for

57 Leonard Kukić, “Socialist Growth Revisited: Insights from Yugoslavia”, European Review of Economic History 22 (2018): 403-429, 418.

58 "Situation Report: Yugoslavia, 4 May 1987", 4 May 1987. HU OSA 300-8-47-217-3; Records of Radio Free Europe/Radio Liberty Research Institute: Publications Department: Situation Reports; Open Society Archives at Central European University, Budapest.

59 Goran Musić, "Yugoslavia: Workers' Self-Management as State-Paradigm", in Ours to Master and To Own. Workers' Councils from the Commune to the Present, ed. Immanuel Ness and Dario Azzellini (Chicago: Haymarket Books, 2011), 172-19o. According to Musić (in a private communication), Yugoslavia was structurally more open to productivity bargains than the shortage economies of Eastern Europe.

6o "Situation Report: Hungary, 13 January 1981", 13 January 1981. HU OSA 30o-8-47-1121; Records of Radio Free Europe/Radio Liberty Research Institute: Publications 
economic inequality in Hungary was nevertheless not only pursued through wage reform, which - as one official put it - was likely to "stop at the factory gates". ${ }^{61}$ It was also pursued (and in this lies the originality of late socialism in Hungary) through the creation of semi-autonomous subcontracting teams of workers within factories. These teams comprised up to 30 workers who were allowed, in their spare time, to negotiate contracts with management for the production of goods using the factory's machinery and materials. By the mid1980 s, almost a quarter of a million Hungarian workers out of a total workforce of five million were engaged in such schemes, bargaining with management over higher wages; a process that led not only to significant wage differentiation, but also to a re-segmentation of the workforce between a privileged minority and the rest. ${ }^{62}$ This legal innovation, as David Stark showed, merely brought to light well-established shop floor practices, officialising workers' control and the bargaining routine over higher pay, extra-hours and better access to machinery that always came with it. ${ }^{63}$

This brief examination of wage reform in state socialist Eastern Europe shows the conundrum faced by the policymakers involved in seeking to organize productivity bargains by means of wage reform. Almost every wage reform after the 196os was intended to rectify two of the problems inherent in a centrally-planned economy: either norm over-fulfilment and high wage dispersion, or various forms of egalitarianism and low wage dispersion. Almost every other wage reform implemented during the 1970s and 1980s ended up reproducing the same problems it was supposed to rectify. The back and forth between cutting down on norm over-fulfilment and encouraging low wage dispersion, and struggling against "wage levelling" to promote high wage dispersion was structurally determined by what I have termed the antinomy of workers' control. It is indeed one of the historical peculiarities of the socialist shortage economy to have turned wage policy into the pillar of various cyclical reform attempts. This historical peculiarity, I argue, was causally influenced by the phenomenon of workers' control, which was itself perceived by managers

Department: Situation Reports; Open Society Archives at Central European University, Budapest, 15 .

61 "Situation Report: Hungary, 15 December 1982", 15 December 1982. HU OSA 30o-8-47113-18; Records of Radio Free Europe/Radio Liberty Research Institute: Publications Department: Situation Reports; Open Society Archives at Central European University, Budapest, 14 .

62 László Neumann, "Circumventing Trade Unions in Hungary: Old and New Channels of Wage Bargaining", European Journal of Industrial Relations 3, no. 2 (1997): 185.

63 David Stark, "Rethinking Internal Labor Markets: New Insights from a Comparative Perspective", American Sociological Review 51, no. 4 (1986): 492-504. 
and policymakers either as a problem to be solved in search for higher productivity or, more often, as a solution to improve economic efficiency. Every time new "scientific" norms were supposed to boost productivity, workers' control was deemed a problem for the very simple reason that the quintessential veterans of the shop floor were able to manipulate the norms. Every time the shortage economy bumped into "bottlenecks", faulty supply, "storming" and the like, the very same veterans were called upon to put in the extra hours, reach the planned quotas and save face.

On the socialist shop floors, therefore, rather than Taylorism subjecting a vast mass of atomized and oppressed workers to the rhythms of the stopwatch, as Haraszti would have it, some workers always managed to command sufficient control of the production process to afford themselves respite, better incomes and a modicum of leverage in their relationship with management. With regard to Fordist productivity bargaining premised on the payment of higher wages in exchange for more managerial control of the production process, state socialist Eastern Europe generally saw average monetary wages grow faster than labour productivity after the period of wage restraint of the 1950s. ${ }^{64}$ If this observation is accurate, then Bahro's "quantitative compensations" such as bubbles of modest consumerism and urban expansion during the golden Eastern European decade of the 197os - were strictly politically motivated, and mere socialist concessions to the first generation of socialist workers rather than genuine Fordist bargains. ${ }^{65}$

\section{Conclusion}

I started this chapter with one possible answer to the following question: for writing a general history of the left in the twentieth century, how should one think about the trajectory of the working class under state socialism? The experience of East European workers between 1945 and 1989 was interpreted by an Italian trade union leader as a grim lesson about Taylorism and Fordism running amok. This was an understanding Trentin took from the writings of a couple of influential dissidents. Granted, this was an idiosyncratic interpretation

64 "Industrial Wages and Labor Productivity in Eastern Europe", 5 September 1978. HU osA 300-8-3-16266; Records of Radio Free Europe/Radio Liberty Research Institute: Publications Department: Background Reports; Open Society Archives at Central European University, Budapest.

65 See also Peter Hübner, Arbeit, Arbeiter und Technik in der DDR 1971 bis 1989 (Bonn: J.H.W. Dietz Verlag, 2014). 
and - as I have tried to show - a deeply misleading one, but the practice of looking across the Iron Curtain for such lessons was once common, at least on the left. For much of the 1970s and 1980s, Yugoslav self-management and the Polish independent trade union Solidarność served as sources of inspiration for rethinking political strategies and renewing the conceptual vocabulary of the West European left. The narrative outlined by La Città del lavoro, however, does not accurately depict the experience of workers in Eastern Europe before 1989. The overarching story of an "original sin" attributed to Lenin and his followers' fascination with Taylorism and Fordism that ill prepared the left to navigate the global transformation of the 1970s rests on shaky ground. Used by Trentin in support of his account of the failure of the left in Western Europe, the dissident writings of Miklós Haraszti and Rudolf Bahro cannot be taken as generalized depictions of labour relations under state socialism. Nor should the homogenizing concepts of Taylorism and Fordism be permitted to erase the historical specificity of macroeconomic contexts that lacked the basic preconditions for securing "high wages - high consumption" social contracts.

In this chapter, I have suggested that "workers' control" - a category of analysis resurrected by David Montgomery in the 1970s - might prove more profitable for exploring both the lived experience of entire categories of workers and the policy decisions taken by communist governments. This notion, I further contend, might prove equally valuable in understanding the emergence of capitalism in Eastern Europe after 1989. Scholarship on the industrial transformation of the region in the aftermath of the collapse of state socialism has focused predominantly on processes of privatization and deindustrialization. Within these frameworks of interpretation, post-socialist workers appear mostly as symbolically dispossessed Geldsubjekten ohne Geld ${ }^{66}$ : eking out a living on the margins of industrial ruins, struggling against mass unemployment, taking early retirement and buy-out options, pooling resources across the urban/rural divide and kinship networks, or killing time on low wage jobs. Studies of post-socialist trade unions, moreover, customarily examine defensive struggles against plummeting living standards, plant closures, lay-offs and the general collapse of union density throughout the past two decades. ${ }^{67}$

66 The expression belongs to Robert Kurz, Der Kollaps der Modernisierung: Vom Zusammenbruch des Kasernensozialismus zur Krise der Weltökonomie (Frankfurt am Main: Eichborn Verlag, 1991), 225.

67 The amount of literature is too vast to quote. Two landmark studies in this vein are David Kideckel, Getting By in Postsocialist Romania: Labor, the Body, and Working-Class Culture (Bloomington: Indiana University Press, 2008) and Adam Mrozowicki, Coping with Social Change: Life Strategies in Poland's New Capitalism (Leuven: Leuven University Press, 2011). For a recent general survey of trade-unionism in the region see Martin Myant, "Economies 
This strand of literature builds on the double constitutive paradox of postsocialism across Eastern Europe: the transition from centrally planned to market economies on the one hand, and on the other, the deep social and cultural implications of social change in essentially egalitarian societies. ${ }^{68}$ "Rebuilding the ship at sea" after 1989 implied a sudden spike in inequality, "shock therapies", the rapid accumulation (and display) of private wealth, the erosion of state-sponsored welfare and the sidelining of working-class dispositions, voices and lives. Research agendas construed in light of these characteristics of post-socialism have no need for the concept of "workers' control". Unionized or not, workers contemplating unemployment, precarity and a future without work are far removed from the type of "quintessential workers" analysed by Montgomery, Kemény or Burawoy. Nevertheless, post-socialist Eastern Europe offers plenty of cases of effective industrial restructuring via privatization and foreign direct investment in an entire array of industries; from textile and food processing to car manufacturing and steel. In these cases, the issue of workers' control was arguably the most important socialist legacy to be overcome through disciplinary campaigns, productivity bargains and the reorganization of shop floor routines and workplace solidarities. ${ }^{69} \mathrm{La}$ Città del lavoro does not help us to grasp the historical trajectory of state socialism, but it could certainly come in useful for understanding the tremendous success of capitalism in contemporary Eastern Europe.

\section{Bibliography}

Assan, Georges G., La question du contrôl ouvrier en Italie, avec un aperçu dans les autres pays (Paris: Marcel Giard, 1922).

Undergoing Long Transition: Employment Relations in Central and Eastern Europe", in The Oxford Handbook of Employment Relations: Comparative Employment Systems, ed. Adrian Wilkinson, Geoffrey Wood and Richard Deeg (Oxford: Oxford University Press, 2014).

68 Institutional Design in Post-Communist Societies: Rebuilding the Ship at Sea, ed. Jon Elster, Claus Offe and Ulrich K. Preuss (Cambridge: Cambridge University Press, 1998) and Branko Milanović, Income, Inequality, and Poverty during the Transition from Planned to Market Economy (Washington: The World Bank, 1998).

69 See the masterful analysis of "workers' control" before and after the takeover of the Dacia factory by Renault in contemporary Romania by Ştefan Guga, "Low-Cost Fordism? The Antinomies of Class in the Romanian Automobile Industry, 1989-2016" (PhD Dissertation: Central European University, 2017). Compare with Elizabeth C. Dunn, Privatizing Poland. Baby Food, Big Business, and the Remaking of Labor (Ithaca: Cornell University Press, 2004). 
Bahro, Rudolf, Die Alternative. Zur Kritik des real existierenden Sozialismus (Köln: Europäische Verlangsanstalt, 1977).

Bahro, Rudolf, Eine Dokumentation (Köln: Europäische Verlangsanstalt, 1977).

Bahro, Rudolf, Plädoyer für schöpferische Initiative: Zur Kritik von Arbeitsbedingungen im real existierenden Sozialismus (Köln: Bund Verlag, 1980).

Blaga, I., and F. Burtan, Principiul leninist al cointeresării materiale (Bucharest: Editura Politică, 1961).

Brenner, Robert, The Economics of Global Turbulence: The Advanced Capitalist Economies from Long Boom to Long Downturn, 1945-2005 (London: Verso, 2006).

Brown, Jonathan C., ed., Workers' Control in Latin America, 1930-1979 (Chapel Hill: The University of North Carolina Press, 1997).

Burawoy, Michael, "Working in the Tracks of State Socialism", Capital \& Class 33, no. 2 (2009): 33-64.

Burawoy, Michael, and János Lukács, The Radiant Past. Ideology and Reality in Hungary's Road to Capitalism (Chicago: University of Chicago Press, 1992).

Carrieri, Mimmo, "Tra politica e organizzazione del lavoro: Fordismo da regolare, Taylorismo da controllare", in Bruno Trentin: lavoro, libertà, conoscenza, ed. Alessio Gramolati and Giovanni Mari (Florence: Firenze University Press, 2010), 95-106.

Casellato, Alessandro, "Bruno Trentin", Belfagor 64, no. 3 (2009): 291-314.

Cho, Soon-Kyoung, "How Cheap is 'Cheap Labor'? The Dilemmas of Export-led Industrialization" (PhD Dissertation, University of California, Berkeley, 1987).

Clarke, Simon, "What in the F---'s Name is Fordism", in Fordism and Flexibility: Divisions and Change, ed. N. Gilbert, R. Burrows and A. Pollert (London: Macmillan, 1992), 13-30.

Cosaşu, Radu, Opere IV. Supravieţuirile: ı. Rămăşiţele mic-burgheze, 2. Armata mea de cavalerie (Iaşi: Polirom, 2011).

Drach, Marcel, "Crise du travail et non-lieu du fordisme dans les économies de type soviétique", Revue d'études comparatives East-Ouest 14, no. 1 (1983): 105-120.

Dunn, Elizabeth C., Privatizing Poland. Baby Food, Big Business, and the Remaking of Labor (Ithaca: Cornell University Press, 2004).

Edwards, Richard, Contested Terrain: The Transformation of the Workplace in the Twentieth Century (New York: Basic Books, 1979).

Elster, Jon, Claus Offe, and Ulrich K. Preuss, ed., Institutional Design in Post-Communist Societies: Rebuilding the Ship at Sea (Cambridge: Cambridge University Press, 1998).

Filtzer, Donald, "Labor Discipline, the Use of Work Time, and the Decline of the Soviet System, 1928-1991", International Labor and Working-Class History 50 (1996): 9-28.

Frieden, Jeffry A., Global Capitalism: Its Fall and Rise in the Twentieth Century (New York: W.W. Norton \& Company, 2007).

Friedmann, Georges, Le travail en miettes. Spécialisation et loisirs (Paris: Gallimard, 1956). 
Glyn, Andrew, Capitalism Unleashed: Finance, Globalization, and Welfare (Oxford: Oxford University Press, 2007), 104-129.

Grama, Adrian, Laboring Along. Industrial Workers and the Making of Postwar Romania (Berlin: De Gruyter, 2019).

Gramsci, Antonio, Selections from the Prison Notebooks, trans. ed. Quinn Hoare and Geoffrey Smith (New York: International Publishers, 1971).

Greenstein, David E., "Assembling Fordizm: The Production of Automobiles, Americans, and Bolsheviks in Detroit and Early Soviet Russia", Comparative Studies in Society and History 56, no. 2 (2014): 259-289.

Guga, Ştefan, "Low-Cost Fordism? The Antinomies of Class in the Romanian Automobile Industry, 1989-2016” (PhD Dissertation: Central European University, 2017).

Haraszti, Miklós, A Worker in a Worker's State. Translated by Michael Wright (New York: Universe Books, 1978).

Harvey, David, The Limits to Capital (London: Verso, 2006).

Hübner, Peter, Arbeit, Arbeiter und Technik in der DDR 1971 bis 1989 (Bonn: J.H.W. Dietz Verlag, 2014).

"Introduction to Miklós Haraszti", New Left Review, no. 91, (May-June, 1975): 5-8.

Kemény, István, "La chaîne dans une usine hongroise", Actes de la recherche en sciences sociales, Vol. 24 (1978): 62-77.

Kideckel, David, Getting By in Postsocialist Romania: Labor, the Body, and WorkingClass Culture (Bloomington: Indiana University Press, 2008).

Kornai, János, The Socialist System: The Political Economy of Communism (Oxford: Claredon Press, 1992).

Kukić, Leonard, "Socialist Growth Revisited: Insights from Yugoslavia", European Review of Economic History 22 (2018): 403-429.

Kurz, Robert, Der Kollaps der Modernisierung: Vom Zusammenbruch des Kasernensozialismus zur Krise der Weltökonomie (Frankfurt am Main: Eichborn Verlag, 1991).

Lee, Ching Kwan, Gender and the South China Miracle: Two Worlds of Factory Women (Berkeley: University of California Press, 1998).

Lichtenstein, Nelson, "David Montgomery and the Idea of 'Workers' Control' ", Labor. Studies in Working-Class History of the Americas 10, no.1 (2013): 65-71.

Linden, Ronald H., "Socialist Patrimonialism and the Global Economy: The Case of Romania", International Organization 40, no. 2 (1986): 347-380.

Linhart, Robert, L'Établi (Paris: Editions de Minuit, 1981).

Link, Stefan, "Transnational Fordism: Ford Motor Company, Nazi Germany, and the Soviet Union in the Interwar Years" (PhD Dissertation, Harvard University, 2012).

Maier, Charles S., "The Postwar Social Contract", International Labor and Working-Class History 50 (1996): 148-156.

Milanović, Branko, Income, Inequality, and Poverty during the Transition from Planned to Market Economy (Washington: The World Bank, 1998). 
Montgomery, David, Workers' Control in America: Studies in the History of Work, Technology, and Labor Struggles (Cambridge: Cambridge University Press, 1979).

Mrozowicki, Adam, Coping with Social Change: Life Strategies in Poland's New Capitalism (Leuven: Leuven University Press, 2011).

Musić, Goran, "Yugoslavia: Workers' Self-Management as State-Paradigm", in Ours to Master and To Own. Workers' Councils from the Commune to the Present, ed. Immanuel Ness and Dario Azzellini (Chicago: Haymarket Books, 2011), 172-19o.

Myant, Martin, "Economies Undergoing Long Transition: Employment Relations in Central and Eastern Europe", in The Oxford Handbook of Employment Relations: Comparative Employment Systems, ed. Adrian Wilkinson, Geoffrey Wood, and Richard Deeg (Oxford: Oxford University Press, 2014), 359-384.

Ness, Immanuel, and Dario Azzellini, ed., Ours to Master and To Own. Workers' Councils from the Commune to the Present (Chicago: Haymarket Books, 2011).

Neumann, László, "Circumventing Trade Unions in Hungary: Old and New Channels of Wage Bargaining”, European Journal of Industrial Relations 3, no. 2 (1997): 183-202.

Pialoux, Michel, "Alcool et politique dans l'atelier. Une usine de carrosserie dans la décennie 1980s", Genèses 7, no. 1 (1992): 94-128.

Pittaway, Mark, "The Reproduction of Hierarchy: Skill, Working-Class Culture, and the State in Early Socialist Hungary", The Journal of Modern History 74, no. 4(2002): 737-769.

Pula, Besnik, Globalization under and after Socialism. The Evolution of Transnational Capital in Central and Eastern Europe (Stanford: Stanford University Press, 2018).

Rachmuth, Ion, "Trade between Countries with Different Socio-Economic Systems", Soviet and Eastern Foreign Trade 4, no. 1 (1968): 3-17.

Rose, Sonya O., "Class Formation and the Quintessential Worker", in Reworking Class, ed. John R. Hall (Ithaca: Cornell University Press, 1997), 133-166.

Saldern, Adelheid von, and Rüdiger Hachtmann, "Das fordistische Jahrhundert. Eine Einleitung”, Zeithistorische Forschungen 2, no. 6, (2009): 174-185.

Siegelbaum, Lewis, "Soviet Norm Determination in Theory and Practice, 1917-1941", Soviet Studies 36, no. 1 (1984): 45-68.

Sirianni, Carmen, "Workers' Control in Europe: A Comparative Sociological Analysis", in The Experience of Labor in Europe and America 1900-1925, ed. James E. Cronin and Carmen Sirianni (Philadelphia: Temple University Press, 1983), 254-310.

Stark, David, "Rethinking Internal Labor Markets: New Insights from a Comparative Perspective”, American Sociological Review 51, no. 4 (1986): 492-504.

Supiot, Alain, "Introduction", in La Cité du travail. Le fordisme et la gauche, ed. Bruno Trentin (Paris: Fayard, 2012), 13-32.

Trentin, Bruno, La città del lavoro: Sinistra e crisi del fordismo (Milan: Feltrinelli, 1997). Turkish Comisso, Ellen, “A Worker in a Worker's State”, Telos 21, no. 54 (1982): 213-219. Wolfe, Joel, "The Social Subject versus the Political: Latin American Labor Studies at a Crossroads", Latin American Research Review 37, no. 2 (2002): 244-262. 